\title{
Stem Cell Banking-Awareness and Acceptance by Expecting Mothers in Mumbai Region
}

\author{
Abha Ashish Wankhede ${ }^{1} \&$ Kavita Laghate ${ }^{2}$ \\ ${ }^{1}$ K. J. Somaiya Institute of Management Studies and Research, Maharashtra, India \\ 2 Jamnalal Bajaj Institute of Management Studies, Maharashtra, India \\ Correspondence: Abha Ashish Wankhede, K. J. Somaiya Institute of Management Studies and Research, \\ Vidyanagar, Vidyavihar, Mumbai 400077, Maharashtra, India. Tel: 912-267-283-132. E-mail: \\ abha@somaiya.edu
}

Received: July 21, 2015

Accepted: September 28, $2015 \quad$ Online Published: November 25, 2015

doi:10.5539/ijbm.v10n12p181

URL: http://dx.doi.org/10.5539/ijbm.v10n12p181

\begin{abstract}
Stem cell technology is the breakthrough in Medical science. It seems to be the solution for all the human diseases and has the potential to change the way we live. Fatal diseases will cease to be fatal anymore with this innovation in medical science. Considering its promising endowment many countries have adopted Stem Cell Banking and Medical research and curative studies are growing in this area. This paper explores the pregnant women's awareness and acceptance of cord blood stem cells in Mumbai region. It is an empirical study to understand the association between the 'Awareness and Acceptance of Stem Cell Banking' and the demographic profile of the expecting mothers, the effect of the environmental factors such as Gynecologist initiative, promotional activities of Stem Cell Banks, cost associated with storage, and attitude towards preventive health care.

Methodology adopted-Questionnaire was administered among the expecting mothers in Mumbai region and Bi-variate statistical analysis, cross tabulation, chi-square data analysis tool were adopted to understand the association among the variables defined.

The authors have done a substantial literature review of recent news articles and papers publications to understand the stem cell technology and its benefits. This paper highlights future scope of research that can be carried out in this area with reference to practical application so that our Government can reap the benefits of this innovation in medical science for the citizens of our country.
\end{abstract}

Keywords: stem cell, cord blood, stem cell banking

\section{Introduction}

Stem cells are the body's "master" cells that regenerate. Each new cell has the potential to either remain a stem cell or become another type of cell with a more specialized function - such as a muscle cell, a red blood cell or a nerve cell. These cells are responsible for the repair of our body. They have the potential for providing cells and tissues, and can save the child's life from as many as 75 serious ailments, like hemophilia, thalassemia, blood cancer and immunity related genetic disorders. Medical research shows that the stored stem cell of a child may treat many diseases of the parent also and hence become a 'lifeline' for the entire immediate family. The heart, liver, kidney, brain, can actually be cultivated in the environment outside of our body. There are various sources of stem cells, such as umbilical cord blood, bone marrow, peripheral blood, menstrual blood, skin, teeth, placental tissue, human embryos, and milk teeth of children and healthy wisdom teeth of adults. This paper only focuses on the Cord blood banking source of Stem Cells.

Stem cell banking is the process of preserving your stem cells at temperatures several degrees below freezing point (Cryo-preservation). There are two types of cord blood banking- Private and Public. In the Private banking, no one outside of your family can decide to dispose of these cells, give them away or use them for research; a transplant of these cells can be made to that child, or to the siblings or parents and in rare cases, to any other relatives as well. Private banking provides peace of mind of having the cells available to you whenever there is any need but this comes with a financial cost to have the cells collected, processed and stored. In the Public banking during child birth the cells are not discarded as medical waste, but are used to help people. They could 
match to someone searching the public registries because they need a transplant. There is no cost to the parents for public donation and the customer/needy will pay for the cost of storage. The donors have no right to use the donated stem cells.

\section{Literature Review}

In a country like India, public hospitals are called Government hospitals that provide health care free of cost to the Indian citizens. These are usually state funded. There are many hospitals run by charitable trust, which are run at a subsidized medical treatment charges. There are also private hospitals, some of them have state of the art facilities and charge a premium. There are many private Institutes, Hospitals and Industries involved in Stem Cell Research and many Stem Cell Banks operating in India.

Any new medical concept gains credibility among people only if there is involvement of the doctors. The Government hospitals and doctors are not yet recommending the stem cell banking. Currently in India, there are no laws governing stem cell banking, but the health ministry has prepared draft rules for umbilical cord blood banking and has put them up for public consultation. India plans to regulate the growing business of stem cell banking. These rules lay out the requirements for collection, processing, testing, storage and banking and release of stem cells derived from umbilical cord blood. They also specify the norms for transportation of these cells and the requirements for their release. At the global level there are many ethical issues related to the cord blood banking concept that need to debated and sorted out which will eventually facilitate the states and countries to define proper rules and regulation for this area.

The stem cell banking market in India will grow at a CAGR of 37.85\% over the period 2014-2019. Leading stem cell private banks in India have set up sales forces within their organizations where trained medical representatives visit potential customers' homes and educate them about the concept, collection, and processing. There are many packages available with different service level agreements, a ballpark figure for 21 yrs of storage ranges from Rs 75000 to Rs 300 000. Installment payments and EMIs are also available. Inclusion of stem cell storage and treatment is foreseen to be included in the Medical insurance policy. This will be the major driver of growth to this area.

In Taiwan market, the acceptance and decision to opt for stem cell storage by the Taiwanese women was found to be dependent on many factors. First the product itself, cord blood banking awareness of its benefits and applications. Second is the price, quality, usability, ethical issues and the attitude towards preventive health care. Third are the psychological, personal and social factors such as demographics, previous experience, social class and reference groups and family influence.

In the European continent (France, Germany, Italy, Spain and UK), study reveals that there is a strong preference for cord blood donation to public banking. The women their across the economic status and household income feel the same. Almost $89 \%$ of pregnant women are ready to store the cord blood and out of these $76 \%$ are ready to donate the cord blood to public banks and an even larger number of women are ready to donate their cord blood for research in this in this area too.

\subsection{Purpose of the Study}

Stem Cell seems to be the solution for all the human diseases and is a break-through in scientific research that can change the way we live. The fatal diseases will cease to be fatal with this innovation in medical science. The following research questions elaborate the specific research objectives.

\subsection{Research Questions}

1) To learn the benefits of stem cell storage and its applications.

2) To study the awareness level and acceptance of Stem cell storage among the expecting mothers in Mumbai City.

3) To understand the association between the 'Awareness and Acceptance of Stem Cell Banking and the demographic profile of the expecting mothers'.

4) To understand the association between the 'Awareness and Acceptance of Stem Cell Banking and the attitude of expecting mothers towards preventive health-care'.

5) To study the influence of the environment factors such as Gynaecologist (Doctor) initiative, promotional activities of Stem Cell Banks and the cost associated with storage on the expecting mothers and their decisions to opt for donation of Stem cells. 


\section{Research Methodology}

The survey research method was adopted to study the awareness and acceptance of Expecting Mothers in Mumbai region. Questionnaire was administered among the expecting mothers in Mumbai region and chi-square data analysis tool was adopted to understand the association among the variables defined.

\subsection{Variables}

- Dependent variable

1) Awareness of Stem Cell Storage among the Expecting mothers.

2) Acceptance of Stem Cell Storage technology by the expecting mothers.

3) Inclination of expecting mothers to opt for Stem Cell Storage of their baby or be ready to Donate the stem cell of their baby

- Independent variable

Demographic profile of the expecting mother: Age, Education, Profession, Family Income, Location of residence, Type of residence, Family size and Family type.

1) Gynecologist initiatives to promote Stem Cell storage.

2) Cost of Stem Cell Storage.

3) Government's sensitivity.

4) Attitude of expecting mothers towards preventive health care.

\section{Theoretical Framework}

The Marketing acronym AIDA is a handy tool to understand the process of consumer behavior when they are exposed to new things/ technology/ products/ services.

1) Attention (or Attract or Awareness).

2) Interest.

3) Desire.

4) Action.

These are the four steps you need to take your audience through if you want them to buy your idea or your product. The Marketing/Advertising model is used below to study the Awareness, Acceptance and Action/Inclination of expecting mothers for the new idea of Stem Cell Storage of their baby.

Table 1. The marketing/advertising model

\begin{tabular}{|c|c|c|c|}
\hline & Part I & Part II & Part III \\
\hline $\begin{array}{l}\text { Dependent } \\
\text { Variable }\end{array}$ & $\begin{array}{l}\text { Awareness of Stem Cell Storage } \\
\text { among the expecting mothers }\end{array}$ & $\begin{array}{l}\text { Acceptance of Stem Cell } \\
\text { Storage technology by the } \\
\text { expecting mothers }\end{array}$ & $\begin{array}{l}\text { Action/Inclination of } \\
\text { expecting mothers to opt } \\
\text { for Stem Cell Storage of } \\
\text { their baby or be ready to } \\
\text { Donate the stem cell of } \\
\text { their baby }\end{array}$ \\
\hline $\begin{array}{l}\text { Independent } \\
\text { Variable }\end{array}$ & $\begin{array}{l}\text { Demographic profile of the } \\
\text { expecting mother- Age, Education, } \\
\text { Profession, Place of residence, type } \\
\text { of residence, family income. }\end{array}$ & $\begin{array}{l}\text { Awareness of Stem Cell } \\
\text { Storage among the expecting } \\
\text { mothers, Cost of Storage } \\
\text { technology }\end{array}$ & $\begin{array}{l}\text { Awareness, Acceptance of } \\
\text { Stem Cell Storage } \\
\text { technology by the } \\
\text { expecting mothers }\end{array}$ \\
\hline $\begin{array}{l}\text { Moderating } \\
\text { Variable }\end{array}$ & $\begin{array}{l}\text { Government's sensitivity, } \\
\text { Marketing/promotion activities of } \\
\text { Stem Cell Storage Banks, } \\
\text { Gynecologist initiatives to promote } \\
\text { Stem Cell technology }\end{array}$ & $\begin{array}{l}\text { Attitude of expecting mothers } \\
\text { towards Preventive health care. }\end{array}$ & \\
\hline
\end{tabular}




\subsection{Hypotheses}

Ho: The awareness about stem Cell storage is independent of the profile of the expecting mother.

Ha: The awareness about stem Cell storage is dependent on the profile of the expecting mother.

Ho: There is no significant influence of the environment factors (Gynecologist initiatives, Promotional activities by Stem Cell Banks and Government's sensitivity) on generating awareness about Stem Cell storage on the Expecting mothers.

Ha: There is significant influence of the environment factors (Gynecologist initiatives, Promotional activities by Stem Cell Banks and Government's sensitivity) on generating awareness about Stem Cell storage on the Expecting mothers.

Ho: Expecting mothers being aware about Stem cell storage has no influence on their acceptance of Stem cell storage technology for their baby.

Ha: Expecting mothers being aware about Stem cell storage has an influence on their acceptance of Stem cell storage technology for their baby.

Ho: The attitude of expecting mothers towards preventive health care has no significant influence on acceptance/acknowledgment of Stem cell storage technology to be considered for their baby.

Ha: The attitude of expecting mothers and their family members towards preventive health care has significant influence on acceptance/acknowledgment of Stem cell storage technology to be considered for their baby.

Ho: The cost of Stem cell storage has no significant influence on expecting mothers' desire/inclination to consider Private Stem cell Storage of their baby.

Ha: The cost of Stem cell storage has significant influence on expecting mothers' desire/inclination to consider Private Stem cell Storage of their baby.

Ho: Expecting mothers who are aware and accept the Stem cell storage technology show no disposition towards donation of the stem cell of their baby.

Ho: Expecting mothers who are aware and accept the Stem cell storage technology show positive disposition towards donation of the stem cell of their baby.

\subsection{Research Design}

1) Target Population: Expecting mothers in Mumbai region.

2) Sampling Method: Convenience Sampling (Non-Probability).

3) Sample Size: 200 expecting mothers out of this 189 were valid responses.

The survey was conducted through administration of questionnaire in consultation waiting areas of the OPDs (Out Patient Department) of various Government Hospitals and Private Gynecologist clinics in Mumbai city. The questionnaire included 20 multiple choice questions and 6 open ended questions. Some of the respondents did not answer all the questions therefore the total complete respondents for the study is 189. Bivariate statistical analysis, cross tabulation, chi-square was used test the hypothesis.

\section{Major Results}

It was observed that awareness differs as per the age group, education level, type of family (nuclear or Joint) they belong to, and the house-hold income of the family they belongs to. It means that awareness level of the stem cell storage among expecting mothers is not independent of the age, education level, type of family they belong to, and the house-hold income of the family they belongs to. Among the 3 divisions of age groups 20 to 25,25 to 30 and 30 to 35 , the highest age group showed maximum awareness level followed by 25 to 30 and lastly 20 to 25 age group showed least awareness. Higher the education higher was the awareness, higher the house-hold income greater is the awareness. 
Table 2. Age * heard of SC cross tabulation count

\begin{tabular}{|c|c|c|c|c|}
\hline & & \multicolumn{3}{|c|}{ HEARD OF SC } \\
\hline & & YES & NO & Total \\
\hline \multicolumn{5}{|l|}{ AGE } \\
\hline & $20-25$ & 5 & 52 & 57 \\
\hline & $25-30$ & 45 & 57 & 102 \\
\hline & $30-35$ & 15 & 15 & 30 \\
\hline Total & & 65 & 124 & 189 \\
\hline
\end{tabular}

Chi-Square Tests

\begin{tabular}{|l|c|r|r|}
\hline & Value & df & $\begin{array}{c}\text { Asymp. Sig. } \\
\text { (2-sided) }\end{array}$ \\
\hline Pearson Chi-Square & $24.096^{\mathbf{a}}$ & 2 & .000 \\
Likelihood Ratio & 27.820 & 2 & .000 \\
Linear-by-Linear & 19.721 & 1 & .000 \\
Association & 189 & & \\
Nof Valid Cases & & & \\
\hline
\end{tabular}

a. 0 cells (0.0\%) have expected count less than 5 . The minimum expected count is 10.32 .

Table 3. Education * heard of SC cross tabulation count

\begin{tabular}{llll}
\hline & \multicolumn{3}{l}{ HEARD OF SC } \\
\hline & YES & NO & Total \\
\hline EDUCATION & & & \\
10/12TH PASS & 15 & 68 & 83 \\
GRADUATE & 35 & 47 & 82 \\
POST GRADUATE & 15 & 9 & 24 \\
Total & 65 & 124 & 189 \\
\hline
\end{tabular}

\begin{tabular}{|c|c|c|c|}
\hline & Value & df & $\begin{array}{l}\text { Asymp. Sig. } \\
\text { (2-sided) }\end{array}$ \\
\hline Pearson Chi-Square & $20.699^{a}$ & 2 & .000 \\
\hline Likelinood Ratio & 21.178 & 2 & .000 \\
\hline $\begin{array}{l}\text { Linear-by-Linear } \\
\text { Association }\end{array}$ & 20.490 & 1 & .000 \\
\hline N of Valid Cases & 189 & & \\
\hline
\end{tabular}

a. 0 cells $(0.0 \%)$ have expected count less than 5 . The minimum expected count is 8.25 .

Table 4. Family type * heard of SC cross tabulation count

\begin{tabular}{clll}
\hline \multicolumn{4}{l}{ HEARD OF SC } \\
\hline & YES & NO & Total \\
\hline FMAILY TYPE & & & \\
NUCLEAR & 30 & 46 & 76 \\
JOINT & 35 & 78 & 113 \\
Total & 65 & 124 & 189 \\
\hline
\end{tabular}


Chi.Square Tests

\begin{tabular}{|c|c|c|c|c|c|}
\hline & Value & df & $\begin{array}{l}\text { Asymp. Sig. } \\
\text { (2-sided) }\end{array}$ & $\begin{array}{c}\text { Exact Sig. (2- } \\
\text { sided) }\end{array}$ & $\begin{array}{l}\text { Exact Sig. (1- } \\
\text { sided) }\end{array}$ \\
\hline Pearson Chi-Square & $1.455^{\mathrm{a}}$ & 1 & .228 & & \\
\hline Continuity Correction ${ }^{b}$ & 1.103 & 1 & .294 & & \\
\hline Likelihood Ratio & 1.447 & 1 & .229 & & \\
\hline Fisher's Exact Test & & & & .275 & .147 \\
\hline $\begin{array}{l}\text { Linear-by-Linear } \\
\text { Association }\end{array}$ & 1.447 & 1 & .229 & & \\
\hline$N$ of Valid Cases & 189 & & & & \\
\hline
\end{tabular}

a. 0 cells $(0.0 \%)$ have expected count less than 5 . The minimum expected count is 26.14 .

b. Computed only for a $2 \times 2$ table

Table 5. Annual HH income * heard of SC cross tabulation count

\begin{tabular}{clll}
\hline & \multicolumn{3}{l}{ HEARD OF SC } \\
\hline & YES & NO & Total \\
\hline ANNUAL HH INCOME & & & \\
LESS THAN 1 LAC & 0 & 79 & 79 \\
BET 1LAC AND 3 LACS & 25 & 19 & 44 \\
BET 3LAC AND 7 LACS & 15 & 9 & 24 \\
GREATER THAN 7 LACS & 25 & 17 & 42 \\
Total & 65 & 124 & 189 \\
\hline
\end{tabular}

Chi-Square Tests

\begin{tabular}{|l|l|r|r|}
\hline & Value & df & \multicolumn{1}{c|}{$\begin{array}{c}\text { Asymp. Sig. } \\
\text { (2-sided) }\end{array}$} \\
\hline Pearson Chi-Square & $71.380^{\mathbf{a}}$ & 3 & .000 \\
Likelihood Ratio & 94.658 & 3 & .000 \\
Linear-by-Linear & 50.078 & 1 & .000 \\
Association & & & \\
N of Valid Cases & 189 & & \\
\hline
\end{tabular}

a. 0 cells $(0.0 \%)$ have expected count less than 5 . The minimum expected count is 8.25 .

It was observed that the awareness does not differ on which part of the city or area of residence. This means that staying in central suburbs or western suburbs of the Mumbai city has no significant influence on the awareness level of Stem cell storage of the expecting mother. It is also observed that the number of members in their family does not impact their awareness level about stem cell storage.

Table 6. Residence type * heard of SC cross tabulation count

\begin{tabular}{clll}
\hline \multicolumn{4}{l}{ HEARD OF SC } \\
\hline RESIDENCE TYPE & YES & NO & Total \\
CENTRAL SUBURBS & & & \\
WESTERN SUBURBS & 40 & 62 & 102 \\
Total & 25 & 62 & 87 \\
\hline
\end{tabular}


Chi-Square Tests

\begin{tabular}{|l|c|r|r|r|c|}
\hline & Value & df & $\begin{array}{c}\text { Asymp. Sig. } \\
\text { (2-sided) }\end{array}$ & $\begin{array}{c}\text { Exact Sig. (2- } \\
\text { sided) }\end{array}$ & $\begin{array}{c}\text { Exact Sig. (1- } \\
\text { sided) }\end{array}$ \\
\hline Pearson Chi-Square & $2.285^{3}$ & 1 & .131 & & \\
Continuity Correction ${ }^{b}$ & 1.845 & 1 & .174 & .129 & .167 \\
Likelihood Ratio & 2.301 & 1 & .132 & & .087 \\
Fisher's Exact Test & 2.273 & 1 & & & \\
Linear-by-Linear & 189 & & & & \\
Association & & & & & \\
N of Valid Cases & & & & & \\
\hline
\end{tabular}

a. 0 cells $(0.0 \%)$ have expected count less than 5 . The minimum expected count is 29.92 .

b. Computed only for a $2 \times 2$ table

Table 7. No of family members * heard of SC cross tabulation count

\begin{tabular}{cccc}
\hline & \multicolumn{3}{l}{ HEARD OF SC } \\
\hline NO OF FAMILY MEMBERS & NO & Total \\
3-5 & & & \\
$6-9$ & 45 & 71 & 116 \\
& 10 & 34 & 44 \\
GREATER THAN 9 & 10 & 19 & 29 \\
Total & 65 & 124 & 189 \\
\hline
\end{tabular}

Chi-Square Tests

\begin{tabular}{|l|c|r|r|}
\hline & Value & df & $\begin{array}{c}\text { Asymp. Sig. } \\
\text { (2-sided) }\end{array}$ \\
\hline Pearson Chi-Square & $3.649^{a}$ & 2 & .161 \\
Likelihood Ratio & 3.820 & 2 & .148 \\
Linear-by-Linear & 1.084 & 1 & .298 \\
Association & 189 & & \\
N of Valid Cases & & & \\
\hline
\end{tabular}

a. 0 cells $(0.0 \%)$ have expected count less than 5 . The minimum expected count is 9.97 .

It was observed that the percentage of awareness differs as per the type of their residence. Women (expecting mothers residing in affluent 2-3BHK type of residence show higher awareness levels as compared to those staying in less affluent type of residence. Those staying in chawls and slums show the least awareness.

Table 8. Type of residence * heard of SC cross tabulation count

\begin{tabular}{clll}
\hline & HEARD OF SC & \\
\hline & YES & NO & Total \\
\hline TYPE OF RESIDENCE & & & \\
2-3-BHK AND ABOVE & 40 & 16 & 56 \\
1BHK AND 1RK & 15 & 34 & 49 \\
CHAWL AND SLUM & 10 & 74 & 84 \\
Total & 65 & 124 & 189 \\
\hline
\end{tabular}


Chi-Square Tests

\begin{tabular}{|l|r|r|r|}
\hline & Value & df & $\begin{array}{c}\text { Asymp. Sig. } \\
(2-\text {-sided) }\end{array}$ \\
\hline Pearson Chi-Square & $53.179^{\mathrm{a}}$ & 2 & .000 \\
Likelihood Ratio & 54.586 & 2 & .000 \\
Linear-by-Linear & 50.963 & 1 & .000 \\
Association & 189 & & \\
N of Valid Cases & & 1 & \\
\hline
\end{tabular}

a. 0 cells $(0.0 \%$ ) have expected count less than 5 . The minimum expected count is 16.85 .

Profession of the women (expecting mother) has an influence on their awareness level. Women who go out for service or business are more aware as compared to women who stay at home and take care of the house.

Table 9. Work/profession * heard of SC cross tabulation count

\begin{tabular}{llll}
\hline & HEARD OF SC & \\
\hline YES & NO & Total \\
\hline WORK/PROFESSION & & & \\
SERVICE & 15 & 18 & 33 \\
BUSINESS & 15 & 5 & 20 \\
HOUSE WIFE & 35 & 101 & 136 \\
Total & 65 & 124 & 189 \\
\hline
\end{tabular}

Chi-Square Tests

\begin{tabular}{|l|r|r|r|}
\hline & Value & df & $\begin{array}{c}\text { Asymp. Sig. } \\
\text { (2-sided) }\end{array}$ \\
\hline Pearson Chi-Square & $20.923^{3}$ & 2 & .000 \\
Likelihood Ratio & 20.199 & 2 & .000 \\
Linear-by-Linear & 9.291 & 1 & .002 \\
Association & 189 & & \\
N of Valid Cases & & & \\
\hline
\end{tabular}

a. 0 cells $(0.0 \%)$ have expected count less than 5 . The minimum expected count is 6.88 .

Women who are expecting their first child seem to be more aware of the stem cell storage as compared to women who are expecting their second and third child.

Table 10. No of pregnancy * heard of SC cross tabulation count

\begin{tabular}{llll}
\hline & HEARD OF SC & \\
\hline & YES & NO & Total \\
\hline NO OF PREGNANCY & & & \\
FIRST & 50 & 47 & 97 \\
SECOND & 10 & 57 & 67 \\
THIRD & 5 & 20 & 25 \\
Total & 65 & 124 & 189 \\
\hline
\end{tabular}

\section{Chi-Square Tests}

\begin{tabular}{|l|r|r|r|}
\hline & Value & df & $\begin{array}{c}\text { Asymp. Sig. } \\
\text { (2-sided) }\end{array}$ \\
\hline Pearson Chi-Square & $26.198^{2}$ & 2 & .000 \\
Likelihood Ratio & 27.413 & 2 & .000 \\
Linear-by-Linear & 19.093 & 1 & .000 \\
Association & 189 & & \\
N of Valid Cases & & 1800 \\
\hline
\end{tabular}

a. 0 cells (0.0\%) have expected count less than 5 . The minimum expected count is 8.60 . 
It can be observed through the frequency table below that $65 \%$ of expecting mothers are not aware of Stem cell storage. Among those with awareness, Doctors/ Gynecologist contribute only $30.8 \%$ of awareness generation. It is interesting to know that newspaper and friends together $(46.2 \%)$ are the sources of awareness generation among the expecting mothers.

Table 11. Statistical for stem cell storage

\begin{tabular}{lll}
\hline & Frequency & Percent \\
\hline MAGAZINE & 5 & 7.7 \\
INTERNET & 5 & 7.7 \\
NEWSPAPER & 15 & 23.1 \\
WORKPLACE & 5 & 7.7 \\
FRIENDS & 15 & 23.1 \\
DOCTOR & 20 & 30.8 \\
& 65 & 100.0 \\
\hline
\end{tabular}

WHERE FIRST HEARD

\begin{tabular}{|ll|r|r|r|r|}
\hline & & Frequency & Percent & Valid Percent & $\begin{array}{c}\text { Cumulative } \\
\text { Percent }\end{array}$ \\
\hline Valid & MAGAZINE & 5 & 2.6 & 2.6 & 2.6 \\
& INTERNET & 5 & 2.6 & 2.6 & 5.3 \\
& NEWSPAPER & 15 & 7.9 & 7.9 & 13.2 \\
& WORKPLACE & 5 & 2.6 & 2.6 & 15.9 \\
& FRIENDS & 15 & 7.9 & 7.9 & 23.8 \\
DOCTOR & 20 & 10.6 & 10.6 & 34.4 \\
NOT HEARD & 124 & 65.6 & 65.6 & 100.0 \\
Total & 189 & 100.0 & 100.0 & \\
\hline
\end{tabular}

The chi-square analysis indicates that there is significant influence of. The Gynecologist/Doctors initiative in generating awareness of the stem cell storage among expecting mothers in Mumbai region.

Table 12. Gynaecologist mentioned * heard of SC cross tabulation

\begin{tabular}{lllll}
\hline & HEARD OF SC & & \\
\hline & & YES & NO & Total \\
\hline GYNECOLOGIST MENTIONED & YES & 25 & 0 & 25 \\
Total & NO & 40 & 124 & 164 \\
\hline
\end{tabular}

\begin{tabular}{|c|c|c|c|c|c|}
\hline & Value & df & $\begin{array}{c}\text { Asymp. Sig. } \\
\text { (2-sided) }\end{array}$ & $\begin{array}{c}\text { Exact Sig. (2- } \\
\text { sided) }\end{array}$ & $\begin{array}{c}\text { Exact Sig. (1- } \\
\text { sided) }\end{array}$ \\
\hline Pearson Chi-Square & $54.962^{a}$ & 1 & .000 & & \\
\hline Continuity Correction ${ }^{b}$ & 51.663 & 1 & .000 & & \\
\hline Likelihood Ratio & 61.064 & 1 & .000 & & \\
\hline Fisher's Exact Test & & & & .000 & .000 \\
\hline $\begin{array}{l}\text { Linear-by-Linear } \\
\text { Association }\end{array}$ & 54.672 & 1 & .000 & & \\
\hline$N$ of Valid Cases & 189 & & & & \\
\hline
\end{tabular}

The Stem Cell Bank promotion and marketing effort on the awareness of stem cell storage among expecting mothers in Mumbai region. 
Table 13. SC bank rep effort * heard of SC cross tabulation count

\begin{tabular}{lllll}
\hline & \multicolumn{3}{l}{ HEARD OF SC } \\
\hline & & YES & NO & Total \\
\hline & YES & 25 & 5 & 30 \\
SC BANK REP EFFORT & NO & 40 & 119 & 159 \\
Total & & 65 & 124 & 189 \\
\hline
\end{tabular}

\begin{tabular}{|c|c|c|c|c|c|}
\hline \multicolumn{6}{|c|}{ Chi-Square Tests } \\
\hline & Value & df & $\begin{array}{l}\text { Asymp. Sig. } \\
\text { (2-sided) }\end{array}$ & $\begin{array}{l}\text { Exact Sig. (2- } \\
\text { sided) }\end{array}$ & $\begin{array}{l}\text { Exact Sig. (1- } \\
\text { sided) }\end{array}$ \\
\hline Pearson Chi-Square & $37.856^{a}$ & 1 & .000 & & \\
\hline Continuity Correction ${ }^{\mathrm{b}}$ & 35.322 & 1 & .000 & & \\
\hline Likelihood Ratio & 36.877 & 1 & .000 & & \\
\hline Fisher's Exact Test & & & & .000 & .000 \\
\hline $\begin{array}{l}\text { Linear-by-Linear } \\
\text { Association }\end{array}$ & 37.656 & 1 & .000 & & \\
\hline $\mathrm{N}$ of Valid Cases & 189 & & & & \\
\hline
\end{tabular}

a. 0 cells $(0.0 \%)$ have expected count less than 5 . The minimum expected count is 10.32 .

b. Computed only for a $2 \times 2$ table

The attitude of expecting mothers towards preventive health care on their awareness about stem cell storage.

Table 14. Insurance taken * heard of SC cross tabulation count

\begin{tabular}{|c|c|c|c|c|}
\hline & & \multicolumn{3}{|c|}{ HEARD OF SC } \\
\hline & & YES & NO & Total \\
\hline \multicolumn{5}{|c|}{ INSURANCE TAKEN } \\
\hline & LIFE & 30 & 10 & 40 \\
\hline & MEDICAL & 10 & 14 & 24 \\
\hline & NOT TAKEN & 25 & 100 & 125 \\
\hline Total & & 65 & 124 & 189 \\
\hline
\end{tabular}

Chi-Square Tests
\begin{tabular}{|l|c|r|r|}
\hline & Value & df & $\begin{array}{c}\text { Asymp. Sig. } \\
\text { (2-sided) }\end{array}$ \\
\hline Pearson Chi-Square & $41.270^{2}$ & 2 & .000 \\
Likelihood Ratio & 40.592 & 2 & .000 \\
Linear-by-Linear & 40.752 & 1 & .000 \\
Association & 189 & & \\
Nof Valid Cases & \multicolumn{1}{|c|}{189} \\
\hline
\end{tabular}
a. O cells (0.0\%) have expected count less than 5. The
minimum expected count is 8.25.

It was observed that the number of expecting mothers aware of stem cell storage were only $34.4 \%$. In the part B of the questionnaire all the respondents who were unaware were detailed about the Stem Cell Storage technology and the benefits of it for the child. Post this they were asked if they would opt for stem cell storage for their baby. It was observed that the after learning about the benefits the acceptance level rose to $79.4 \%$. It can be inferred that if the awareness level increases the acceptance and this breakthrough in medical science will be accepted by the expecting mothers.

It can be observed from the table below that the maximum number of respondents (total 44.5\%) perceive the cost of stem cell to be around 'between Rs 1 Lac to Rs 3 Lacks', and 33.4\% perceived the cost to be even higher than Rs 3 Lacks, when they were asked about what will be the affordable cost at which they would consider opting for private stem cell storage for their baby, most of them (around 51.8\%) mentioned 'between 10 thousand to 1 Lakh'. The actual cost of stem cell storage is close to the affordable cost of the respondent, starting from Rs 75 000, and also EMI schemes are made available to make it more affordable for masses. It can be inferred that affordable cost is an important factor in determining the acceptance and inclination of the expecting mother to consider private stem cell storage for their baby. 
Table 15. Idea of cost

\begin{tabular}{lllll}
\hline & Frequency & Percent & Valid Percent & Cumulative Percent \\
\hline BET 5K-10K & 4 & 0.02 & 0.02 & 2.1 \\
BET 10K-50K & 18 & 0.10 & 0.10 & 11.6 \\
BET 50K-1LAC & 20 & 0.11 & 0.11 & 22.2 \\
BET 1LAC-2LAC & 40 & 0.21 & 0.21 & 43.4 \\
BET 2LAC-3LAC & 44 & 0.23 & 0.23 & 66.7 \\
BET 3LAC-5LAC & 24 & 0.13 & 0.13 & 79.4 \\
BET 5LAC-10LAC & 19 & 0.10 & 0.10 & 89.4 \\
MORE THAN 10LACS & 20 & 0.11 & 0.11 & 100.0 \\
Total & 189 & 1.00 & 1.00 & \\
\hline
\end{tabular}

\begin{tabular}{lllll}
\hline \multicolumn{5}{l}{ AFFORDABILITY OF PRIVATE SC } \\
\hline & Frequency & Percent & Valid Percent & Cumulative Percent \\
\hline BET 5K-10K & 14 & 7.4 & 7.4 & 7.4 \\
BET 10K-50K & 39 & 20.6 & 20.6 & 28.0 \\
BET 50K-1LAC & 59 & 31.2 & 31.2 & 59.3 \\
BET 1LAC-2LAC & 33 & 17.5 & 17.5 & 76.7 \\
BET 2LAC-3LAC & 19 & 10.1 & 10.1 & 86.8 \\
BET 3LAC-5LAC & 10 & 5.3 & 5.3 & 92.1 \\
BET 5LAC-10LAC & 15 & 7.9 & 7.9 & 100.0 \\
Total & 189 & 100.0 & 100.0 & \\
\hline
\end{tabular}

It is observed from the below table that the respondents would voluntary opt for donating the stem cells of their babies if Government promoted this imitative, almost $74.6 \%$ of them. Almost $50 \%$ of respondents are not aware of any public health programs initiated by the Government. This indicates that the Government needs to promote and market its schemes and initiative more aggressively. The Government program on eliminating Polio is the most effective and had the maximum recall followed by the Government pregnancy program and then the Aids and cancer and blood donation initiatives.

Table 16. Opt if govt promoted SC

\begin{tabular}{lllll}
\hline & Frequency & Percent & Valid Percent & Cumulative Percent \\
\hline YES & 141 & 74.6 & 74.6 & 74.6 \\
NO & 48 & 25.4 & 25.4 & 100.0 \\
Total & 189 & 100.0 & 100.0 & \\
\hline HEARD OF GOVT HEALTH PROGRAMS & & & \\
\hline \multicolumn{5}{c}{} \\
\hline POLIO & Frequency & Percent & Valid Percent & Cumulative Percent \\
DON'T KNOW & 50 & 26.5 & 26.5 & 26.5 \\
PREGANCY PROGRAM & 95 & 50.3 & 50.3 & 76.7 \\
AIDS AND CANCER & 19 & 10.1 & 10.1 & 86.8 \\
TB & 10 & 5.3 & 5.3 & 92.1 \\
BLOOD DONATION & 5 & 2.6 & 2.6 & 94.7 \\
Total & 10 & 5.3 & 5.3 & 100.0 \\
\hline
\end{tabular}

The chi-square analysis show that there is significant influence of the Government sensitivity towards any of the public health initiatives on the awareness and acceptance of the stem cell storage technology among the expecting mothers in Mumbai region. 


\begin{tabular}{|l|r|r|r|}
\hline & \multicolumn{1}{|c|}{ Value } & df & \multicolumn{1}{c|}{$\begin{array}{c}\text { Asymp. Sig. } \\
\text { (2-sided) }\end{array}$} \\
\hline Pearson Chi-Square & $72.352^{\mathrm{a}}$ & 5 & .000 \\
Likelihood Ratio & 76.814 & 5 & .000 \\
Linear-by-Linear & .253 & 1 & .615 \\
Association & 189 & & \\
N of Valid Cases & & & \\
\hline
\end{tabular}

a. 5 cells $(41.7 \%)$ have expected count less than 5 . The minimum expected count is 1.27 .

\section{Conclusion}

The survey reveals that the awareness of the Stem Cell storage in Mumbai city among expecting mothers is dependent on the profile of the expecting mother. The expecting mothers Age, Education, Profession/Work, Type of residence, Household income and the number of her pregnancy (first or second or more). The environmental factors such as the Doctor/Gynecologist, Stem Cell Banks, and the Government sensitivity towards stem cell storage banking does have a significant influence on the expecting mothers awareness and acceptance of Stem cell storage. The attitude of the expecting mothers towards preventive health care also has significant influence on their acceptance of Stem cell storage for their baby. The affordability of this technology is a major factor in considering private stem cell storage for their baby. The survey also reveals that if the expecting mothers are made aware of the unique benefits of the stem cell they are more than willing to donate the stem cell of their baby. It also reveals that if the Government takes initiative to increase awareness and promote this cause then they would be doubly sure and voluntarily donate the stem cells of their babies. Once the Government regulates this industry and the benefits of this technology in public health care becomes convincing the Government can take it up as a major initiate to promote the stem call storage. The Government can take up the project of developing Stem cell storage Banks with collaboration with some private players who have domain expertise. India definitely shows a great potential of growth in the industry provided that people are convinced about the benefit to health and elimination of fatal diseases through this technology. There is an association of awareness of stem cell and the attitude of women towards preventive health care, inclusion of stem cell storage and treatment in medical insurance policy will act as a major growth driver to this space.

\section{Scope for Further Research}

Stem cell treatments: Medical World needs to provide and mandate the process of the Stem cell treatment. Indian Medical and authorized bodies need to work closely with the World bodies to transfer the benefits of this technology to people who need it.

Regulations: The regulatory body needs to be formed and collaborate with the international Regulatory bodies to control and answer the ethical dilemmas that emerge with this technology like human cloning.

Government initiative: in developing Cord Blood Banks and promotion of donation of stem cells as this is currently serving as a solution to the cancer treatment and serves as the replacement to the bone marrow. There is a need to develop a robust ecosystem so that the Government hospitals can have access to the cord blood banks for making it available to the people of the country irrespective of their financial background.

\section{References}

Katz, G., Mills, A., Garcia, J., Hooper, K., McGuckin, C., Platz, A., Rubella, P., Salvaterra, E., Schmidt, A. H., \& Torrabadella, M. (2011). Banking cord blood stem cells: Attitude and knowledge of pregnant women in five European countries. Transfusion, 51(3), 578-586.

Pandeya, R. M. (2010). Tribune Business News [Washington]. Law to regulate stem cell banking in India. Retrieved from http://search.proquest.com/docview/521357300?accountid=31551

Stem Cell-Research News. (2010).

Steven, J. J., \& Antonis, K. H. (2009). Stem cell therapy for cardiac repair: Benefits and barriers. Expert Reviews in Molecular Medicine, 11, 20. http://dx.doi.org/10.1017/S1462399409001124

Yang, M. T. C., \& Robert, K., Roseanne, M. J. (2003). The marketing strategies analysis for the umbilical cord blood banking service. International Journal of Health Care Quality Assurance, 16(6/7), 293-299. 


\section{Copyrights}

Copyright for this article is retained by the author(s), with first publication rights granted to the journal.

This is an open-access article distributed under the terms and conditions of the Creative Commons Attribution license (http://creativecommons.org/licenses/by/3.0/). 